\title{
Albert Hoffstädt: A Tribute
}

Desiderius Erasmus (1466-1536), the finest Latinist of Christendom, leading light in his time of the pan-European Republic of Letters, and still today one of the most famous of Dutchmen, concluded the first full edition of his Adagia in 1508 with comments about the term auris Batava, "Batavian (i.e., Dutch) ear." Disputing Martial's use of the phrase to caricature the Dutch as unrefined and brutish, he praises his countrymen as being the most humane and generous of all peoples, by nature straightforward and untainted by deceit or serious vices, fitted with a high level of education, as well as appreciative of good food and fine wine. Such a description would more than fairly embrace some of the fine qualities of the Dutchman whom we celebrate with this volume of essays, without by any means exhausting them; but there is much more to say about him. Let us begin.

Albert Hoffstädt, editor at the renowned Leiden publishing house of Brill, has done more in his twenty-five years with the company than any other individual in the world of publishing to advance and put before the academic public the widest range of scholarly studies pertaining to East and South Asia. For several centuries Brill had already been known as a leader in the publishing of Asian (as well as Western) humanities. In recent decades Albert Hoffstädt has been the worthy heir and guardian of that lineage, and indeed one might well acknowledge that by dint of his acumen, insight, and good sense, he made himself the very face of Brill's Asian endeavors. A brief surview of his career is required.

After postgraduate work in classics at Utrecht University and eight years with Van Dale Lexicografie where his linguistic expertise resulted in his eventually taking responsibility for Van Dale's German and Dutch dictionaries (the lexicographic passion has stayed with him always), Albert came to Brill in October 1995. For a year he was acquisitions editor for classical antiquity, a field still very close to his heart, but early in 1997 became senior editor for Asian Studies. This included for the first five years responsibility also for Ancient Near East Studies. On and off, due to staff changes, he was heavily involved with Islamic Studies, particularly the second edition of the Encyclopedia of Islam. In 2004 he became publishing manager (i.e., head of the department) for Asian Studies, a position he held until 2013. This role entailed supervision not only of individual monographs but also volumes in various established and newly begun series (among the older, e.g., Sinica Leidensia; among the newer, the Inner Asian Library and the Tibetan Studies Library), as well as all sections except the Ancient Near East and Middle East for the venerable Handbuch der Orientalistik. 
His portfolio has included at one time or another oversight of seven scholarly journals, perhaps the most notable being T'oung Pao, the oldest (founded 189o) and most prestigious international journal of sinology, the supervision of which he exercises to the present day, and $N A N N \ddot{U}$, founded under his hand in 1999 as the first international journal devoted to gender studies in sinology. Since 2013 he has returned to his earlier role as senior acquisitions editor for Asian Studies. Representing Brill internationally, Albert has traveled many times to China as well as to India, Tibet, Nepal, Japan, Taiwan, Singapore, Australia, and Armenia (not to mention of course to North America and most of Europe), in all of which countries he has established both professional and personal bonds. For most of his years superintending Asiatica at Brill, he has been assisted by Ms. Patricia Radder, a shining star in her own right, who ably matches him in her unstinting professionalism, practical judgment, and editorial acumen.

The tales to tell of Albert's kindness, generosity, and encouragement as an editor are countless. One of the editors of the present volume, for instance, can recall how Albert pursued a decade-long persuasion for him to author a dictionary of premodern Chinese and how, once the project was agreed to and underway, Albert advocated successfully for it to be published not only in the usual hardcover format but also as an affordably priced paperback (one of the few ever published by Brill) so as to prove true to its title, A Student's Dictionary of Classical and Medieval Chinese. The other editor recalls Albert's indispensable role in bringing about Brill's Encyclopedia of Buddhism. It was the synergy of this editor's presence in Leiden, Albert's unwavering drive for reliable works on Buddhism, and their long friendship which afforded many opportunities for casual conversations to turn into impromptu planning sessions, that formed the actual genesis of the massive project, two volumes of which, each over a thousand pages, have so far appeared. It was in belatedly and inadequately recognizing Albert's central role in the project, in the Preface to Volume 2, that its author first had the idea for a more substantial public appreciation, an aspiration which has come to fruition with the present volume. While China has been in some ways the central focus of Albert's editorial work, his interest and influence in the areas of Central Asian and Indic studies have been no less important, one of the best examples of the latter being the monumental sevenvolume series of books by Walter Spink on the history and development of the Ajanta caves and their paintings and sculptures, which he was instrumental in bringing to publication.

A fact little-known save to his Dutch colleagues is that Albert is also a published author in his native language. In addition to introductory essays to several publications, from 1996 to 2002 he wrote a monthly column on language 
and wrong thinking for the Van Dale Taalbrief, and from 2012 to the present he has authored a quarterly column of observations on social and linguistic issues in the bulletin of the Amicitia Society. Twenty-four of these latter columns were collected in the booklet Ieder zijn Grutto, published in 2018. He has also published short stories in Dutch literary journals. He modestly refers to all of these writings as "nugae." In English he is the author of "Dutch Sinology and Brill," a fascinating essay on the long history of Brill's involvement with Chinese studies (in Chinese Studies in the Netherlands: Past, Present, and Future, ed. W. Idema [Leiden: Brill, 2014]).

The twenty-two individuals whose offerings to Albert appear in the book at hand could easily have been increased many times over, since so many scholars are in his debt. While it is true that in his editorial capacity he has shepherded more than seven hundred works and authors in the past twenty-five years, his impact does not end there, since at every scholarly congress or meeting he has attended he made a special effort to sit down with scholar after scholar, listen to their interests, and encourage their research. Not all of these discussions resulted in Brill publications, and in this respect his overall impact on Asian studies in particular is not captured even by the impressive number of volumes that have appeared under his direct guidance, and certainly not by the small number of authors who have contributed their studies to him here. We sincerely regret that it was not possible to invite all of those who would surely have wished to express their appreciation. The contributors to this volume are a subset of those who have enjoyed the special pleasure of knowing not only Albert the editor of genius but also Albert the lifelong classicist, fine conversationalist, lover of the arts, urbane polyglot, sly wit, and dear friend. He has a particular gift for invoking in those he favors with his confidence the highest ideals of learning and humanism. If anything approaching a Republic of Letters can be said to exist today in the field of Asian Studies, Albert is the individual who has most fostered it. He is a gentleman at home in several languages and cultures, a connoisseur of literature in French, German, and English, in addition to his native Dutch (and not coincidentally a fluent speaker of all those languages), and forever a devotee of the Greek and Latin classics. One feels better and wiser for knowing him.

We are proud and honored to present to him this volume containing textual tokens of our esteem, in heartfelt gratitude and, above all, friendship.

\section{The Editors}


A Note on the Title and Cover. The title of this book derives from a couplet in a famous poem by the seventh-century Chinese poet Wang Bo 王勃 (649-676), written upon seeing off a friend on a distant journey. The lines read "If within the seas there remains one who truly knows me,/ At the shores of the sky we're as though nearby neighbors" (海內存知已, 天涯若比鄰), and they have become almost proverbial as a statement of enduring friendship, regardless of physical separation. The cover of the book reproduces these lines from a calligraphy scroll presented to Albert Hoffstädt by a Chinese friend and includes from the same scroll an ink-rubbing of an Indic elephant, surprisingly portrayed in a Han-dynasty tomb. 